\title{
PHYLOGENETIC RELATIONSHIP AMONG DIFFERENT VARIETIES AND SPECIES OF CANNA USING MOLECULAR MARKERS
}

\author{
Fatma El-Zahara H. El-Tony \\ Ornamental Plants and Landscape Gardening Res. Dept. (Alexandria), Hort. Res. Inst., A.R.C., \\ Giza, Egypt
}

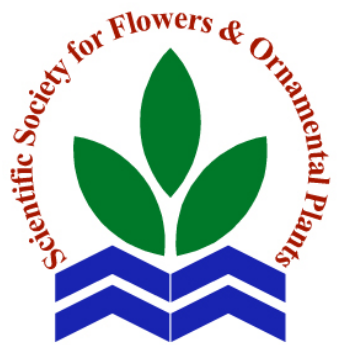

Scientific J. Flowers \& Ornamental Plants, 8(1):165-180 (2021).

Received:

7/2/2021

Accepted:

$25 / 3 / 2021$

Corresponding author: Fatma El-Zahara H. El-tony f.eltony@yahoo.com

ABSTRACT: Canna, the solitary genus of family Cannaceae, represents a group of ornamental plants species. In this investigation an attempt was made to access the genetic relationship among six species and varieties of Canna using RAPD and ISSR techniques. A total of 49 major scorable bands ranging from 200 to $1500 \mathrm{bp}$ were generated from two RAPD and three ISSR primers showing 83.6\% polymorphism. Generally low relationship between tested cultivars/species; and the highest correlation (5.09) was found between Canna lily (C3) and Canna indica red (C2) and between Canna flaccida (C5) and Canna indica red (C2). However, the lowest (3.316) similarity was observed between Canna lily red brilliant (C4) and Canna flaccida (C5). The dendrogram based on the contained data of both RAPD and ISSR which showed that Canna paniculata (C6) was always in a far correlation with the other species and varieties in this study. It was observed that the used primers of both RAPD and ISSR divided the plants according to the flower colour with ignorance to the leaves colour and grouped (C. variegata, $C$. indica red and C. paniculata) together in one cluster, but in the other cluster, the primers grouped them according to the leaves cluster with ignorance of the flower colour (C. flaccida, Canna lily red brilliant and Canna lily). Finally, it might be the same cultivars grouped in other way in case of using other primers or other molecular marker system.

Key words: Canna, varieties, species, ISSR, RAPD, molecular marker.

\section{INTRODUCTION}

The genus Canna comprises of about 51 species of flowering plants having flashy, brilliantly-colored flowered and large tropical foliage. The native of Canna species are South and North America, in addition they have been introduced to Asia and Europe. With the passage of time, they evolved into native varieties (Prince, 2010). Distribution of Canna species is most possibly due to the effect of human dispersal.

Transportation of Canna from their native place might have been the reason for occurrence of beautiful ornamental plant in Europe, Asia and Africa (Maas Van and
Maas, 2008). Most of Canna hybrids are used as cultivated garden ornamentals around the world. Some of wild Canna species are popularly known as elemental species of Canna those like C. glauca, $C$. indica, $C$. iridiflora, $C$. warscwiczii and $C$. flaccida.

The taxonomy of Cannaceae is disputed as it relies on morphological features. Also, the distinguishing features between Canna varieties are poor. No work has been reported on the studies of genetic diversity of Canna cultivars in India and world, except for Piyachomkwan et al. (2002); Patra et al. (2008) and Gupta et al. (2013), who had 
done some experiments with very limited way. The present study was carried out to study the genetic diversity of some cultivated Canna (species and varieties) in Egypt using RAPD (Random amplified polymorphic DNA) primers and ISSR (inter specific sequence repeat).

\section{MATERIALS AND METHODS}

\section{Morphological Analysis:}

Some plants of different species and varieties of Canna were collected from a nursery in King Marriott, Alexandria (A.R.E.). A pot experiment was carried out during one season of 2019 at Faculty of Agriculture, Alexandria University.

Six Canna species and varieties were used in this study which were: Canna variegata "Pretoria" $(\mathrm{C} 1)$ with orange flower and variegated leaves, Canna indica red (C2) with orange flower and red leaves, Canna lily (C3) with white flower and green leaves, Canna lily red brilliant (C4) with red flower and green leaves, Canna flaccida (golden canna) (C5) with yellow flower and green leaves and Canna paniculata (C6) with single orange flower and green leaves (Fig., 1).

The experimental layout was designed to provide a completely randomized design (CRD) containing three replicates. Each replicate had 3 plants. Some morphological characters of Canna were used for characterization and identification of the different Canna species and varieties. The main of these measurements were: plant height, petal color, flower shape, flower form (signal or double), leaf color, leaf shape, width of adult leaf. All measurements were taken on three plants of each species or varieties. These measurements were replicated three times to minimize error where possible.

\section{Molecular diversity studies:}

These molecular studies were carried out in the molecular biology laboratory of the Faculty of Agriculture at the Alexandria University.
RAPD and ISSR PCR based molecular methods were used for the genetic study. Two primers of RAPD and three others of ISSR were used to distinguish among the six Canna species and varieties used in this investigation.

\section{Plant Materials:}

Young fresh leaf material representing six endemic varieties; Canna species were collected from nursery in King Marriott, Alexandria, Egypt. The collected leaves were wrapped between moist tissue papers and kept in the refrigerator at $-50{ }^{\circ} \mathrm{C}$ until DNA extraction.

\section{Purification of Canna DNA (DNA Extraction):}

Major contaminants in crude DNA preparation are RNA, polysaccharides and protein and it is essential to remove them because it will hamper further downstream processing. Also, it was found that Canna DNA extract always remain contaminated with starch when isolated through conventional procedure of Doyle and Doyle (1987). Because of these mentioned before, Kit protocol was used in this study (Biotech Kit, Biovision, Korai) for isolated genomic DNA from the young leaves (the third leaf from the top of plant) of each variety.

\section{Determination of DNA purity and concentration:}

Nanodrop spectrophotometer was used to determine the isolated DNA. The ratio 260/280 was found $1.8-1.99$, this indicated that DNA extract was pure enough for RAPD analysis.

\section{Primers:}

In this study, two RAPD primers and three ISSR primers were used as shown in the Table (1).

Random amplified polymorphism DNA (RAPD):

Each polymerase chain reaction consisted of $2 \mu \mathrm{l}$ of primer, $10 \mu \mathrm{l}$ master mix and $50 \mathrm{ng}$ of genomic DNA. In a Biometra, PCR amplification was performed, T1 


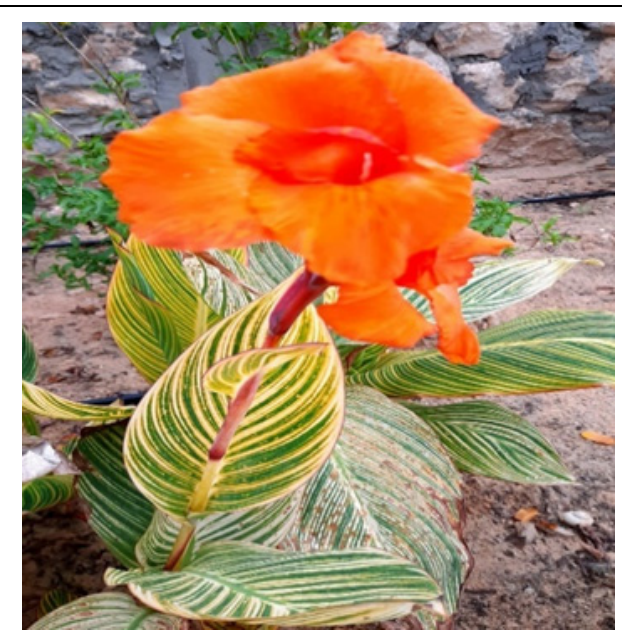

Canna variegata (C1)

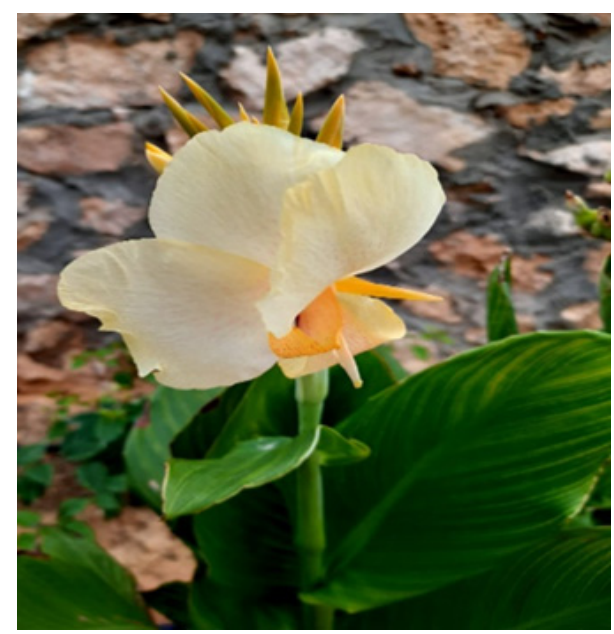

Canna lily (C3)

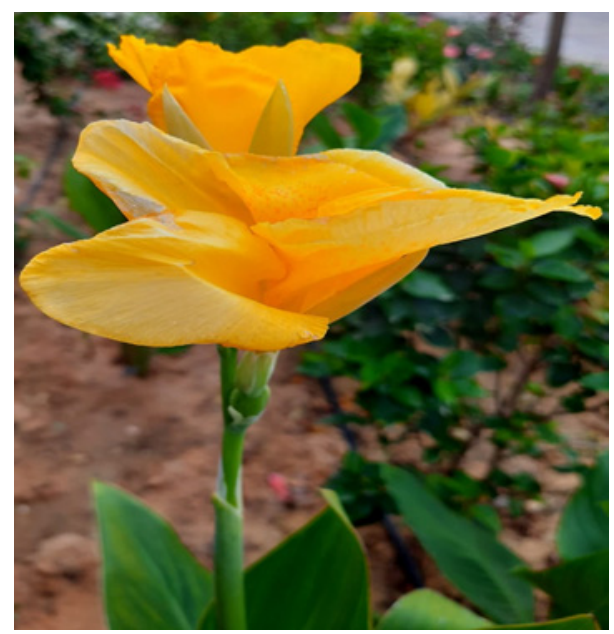

Canna flaccida (C5)

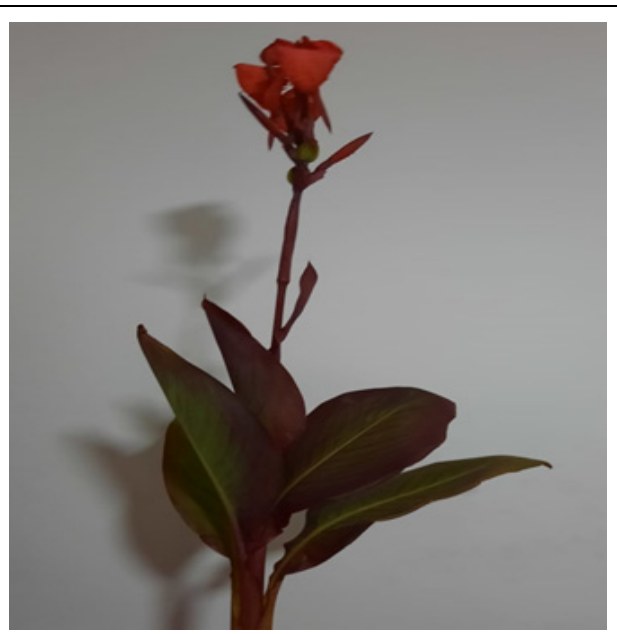

Canna indica red (C2)

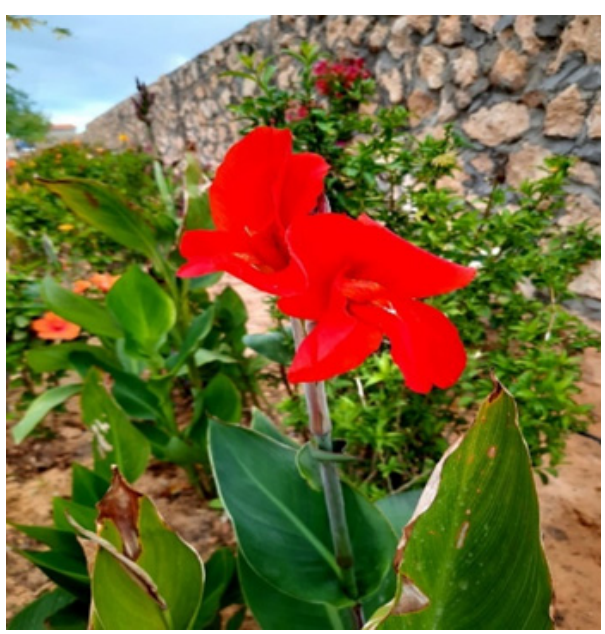

Canna lily red brilliant (C4)

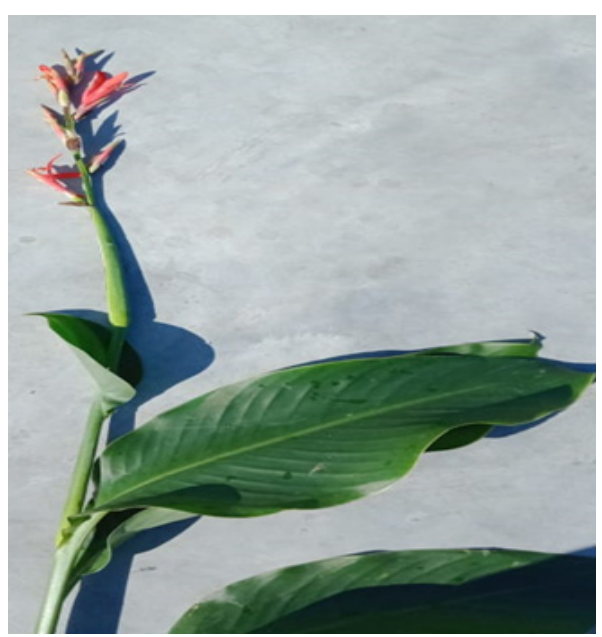

Canna paniculata (C6)

Fig. 1. Different 6 species and varieties of Canna which used in this study. 
Table 1. Represents 5 random primers name, sequences and annealing temperature as well as guanine and cytosine content percentage; two RAPD primers and three ISSR primers.

\begin{tabular}{ccccc}
\hline $\begin{array}{c}\text { Primer } \\
\text { number }\end{array}$ & Primer code & Sequences & GC\% & Tm(c) Value \\
\hline 1 & HB-08 (ISSR) & 5' - GAG AGA GAG AGA GG -3' & 57.14 & 44 \\
2 & HA-98 (ISSR) & 5' - CAC ACA CAC ACA AGT -3' & 46.67 & 43.4 \\
3 & OPS-11 (RAPD) & 5' - AAA GTC GCG G -3' & 60.00 & 32 \\
4 & HB-13 (ISSR) & 5' - GAG GAG GAG GC -3' & 72.73 & 38 \\
5 & OPO-20 (RAPD) & 5' - AAC CCG GTC -3' & 60.00 & 32.0 \\
\hline
\end{tabular}

$T m=$ Temperature of melting.

GC $=$ Guanine and Cytosine ratio (percentage).

gradient thermal cycler for 45 cycles after initial denaturation for $2 \mathrm{~min}$ at $94{ }^{\circ} \mathrm{C}$. Each cycle consisted of denaturation at $95^{\circ} \mathrm{C}$ for 1 min; annealing at $37{ }^{\circ} \mathrm{C}$ for $1.30 \mathrm{~min}$; extension at $72{ }^{\circ} \mathrm{C}$ for $2 \mathrm{~min}$ and final extension at $72{ }^{\circ} \mathrm{C}$ for $2 \mathrm{~min}$. The PCR products were separated on $1.5 \%(\mathrm{w} / \mathrm{v})$ agarose gel. The lengths of the different DNA fragments were determined by using 100 pb DNA ladder. Also, by using gel analyzer program, RAPD fragments were scored as present/absent. Clustering and similarity coefficients were estimated according to Rohlf (1998).

\section{Fingerprinting Data Analysis:}

Each polymorphic band was regard as a bring character and was scored as (0) absence and (1) presence for each sample. It assembled in a data matrix. A similarity matrix was calculated to analyze the genetic relationship among the previous varieties according to the mathematical tools of Nei (1972). In addition, similarities were graphically expressed by using the UPGMA to generate dendrograms. Popgene 32 software package was used in the analysis (Yeh et al., 1997).

On the other hand, correspondence analysis of right vectors from the binary data was performed on the basis of graphically summarized associations within the varieties. This analysis was performed through a batch file by using the software package NTSYS pc (version 20) (Rohlf, 1998).

\section{RESULTS AND DISCUSSION}

The obtained morphological data on the different Canna species and varieties were recorded and shown in Tables 2 and 3 as follow:

In view of lack of information in the area of molecular characterization of genetic variability in cultivated cannas in Egypt, the present study was initiated involving 6 common varieties of Canna (from different Canna species). Molecular markers i.e. RAPD and ISSR were used to assess the genome relationship among these 6 varieties.

In the present study, DNA molecular analyses (RAPD and ISSR) were applied to estimate the genetic diversity and the relationships among the six of the Canna different varieties as shown (Figs., 2-11).

Fig. (2) showed the results which obtained by using HB-O8 add which contains $57.14 \% \mathrm{G}+\mathrm{C}$ (Table, 1). The length of amplified DNA fragments of the PCR products generated by this primer ranged from 200-1500 bp. The number of total bands varied among the varieties, where the lowest number was three amplified bands in Canna flaccida (C5), and the highest number was seven amplified bands in the Canna indica red $(\mathrm{C} 2)$ variety. The total number of amplified bands from the genomic of them is polymorphic bands were five and three monomorphic which presented in varieties. Consequently, the polymorphism percentage was $62.5 \%$. 
Table 2. Morphological information of different vegetative parameters of different species and varieties of Canna.

\begin{tabular}{cccccc}
\hline Species and varieties & Leaf colour & $\begin{array}{c}\text { Vegetative parameters } \\
\text { Plant height } \\
\text { (cm) }\end{array}$ & $\begin{array}{c}\text { No. of } \\
\text { leaves/plant }\end{array}$ & $\begin{array}{c}\text { Leaf (cm) } \\
\text { Length }\end{array}$ & Width \\
\hline C1: Canna variegata & $\begin{array}{c}\text { Variegated green } \\
\text { with white }\end{array}$ & $75.31^{\mathrm{d}}$ & $4.28^{\mathrm{a}}$ & $39.16^{\mathrm{c}}$ & $21.16^{\mathrm{a}}$ \\
C2: Canna indica red & Red & $130.47^{\mathrm{b}}$ & $6.29^{\mathrm{a}}$ & $35.39^{\mathrm{d}}$ & $13.18^{\mathrm{c}}$ \\
C3: Canna lily & Green & $72.26^{\mathrm{e}}$ & $5.14^{\mathrm{a}}$ & $32.47^{\mathrm{e}}$ & $15.28^{\mathrm{b}}$ \\
C4: Canna lily red brilliant & Green & $104.27^{\mathrm{c}}$ & $4.52^{\mathrm{a}}$ & $45.32^{\mathrm{a}}$ & $20.26^{\mathrm{a}}$ \\
C5: Canna flacccida & Green & $103.36^{\mathrm{c}}$ & $4.33^{\mathrm{a}}$ & $41.23^{\mathrm{b}}$ & $15.29^{\mathrm{b}}$ \\
C6: Canna paniculata & Green & $134.18^{\mathrm{a}}$ & $6.32^{\mathrm{a}}$ & $34.24^{\mathrm{de}}$ & $14.42 \mathrm{~b}^{\mathrm{c}}$ \\
\hline
\end{tabular}

Table 3. Morphological information of different flowering parameters of different species and varieties of Canna.

\begin{tabular}{|c|c|c|c|c|c|}
\hline \multirow[b]{2}{*}{ Species and varieties } & \multicolumn{5}{|c|}{ Flowering parameters } \\
\hline & Flower colour & $\begin{array}{c}\text { Spike length } \\
\text { (cm) }\end{array}$ & $\begin{array}{l}\text { Spike diameter } \\
(\mathrm{cm})\end{array}$ & $\begin{array}{c}\text { No. of } \\
\text { flowers/spike }\end{array}$ & $\begin{array}{c}\text { Petals No./ } \\
\text { spike }\end{array}$ \\
\hline C1: Canna variegata & Orange & $28.17^{\mathrm{e}}$ & $2.6^{\mathrm{c}}$ & $7.33^{c}$ & $5+3^{a}$ \\
\hline C2: Canna indica red & Orange & $31.12^{\mathrm{d}}$ & $2.3^{\mathrm{d}}$ & $13.26^{\mathrm{a}}$ & $5+3^{a}$ \\
\hline C3: Canna lily & White & $43.58^{\mathrm{a}}$ & $2.7^{\mathrm{bc}}$ & $7.36^{\mathrm{c}}$ & $5+3^{a}$ \\
\hline C4: Canna lily red brilliant & Red & $29.24^{\mathrm{e}}$ & $3.0^{\mathrm{a}}$ & $4.33^{\mathrm{d}}$ & $5+3^{a}$ \\
\hline C5: Canna flacccida & Yellow & $40.11^{\mathrm{b}}$ & $2.8^{\mathrm{b}}$ & $5.56^{\mathrm{cd}}$ & $5+2^{a}$ \\
\hline C6: Canna paniculata & Orange & $34.25^{\mathrm{c}}$ & $1.3^{\mathrm{e}}$ & $11.26^{\mathrm{b}}$ & $3+2^{\mathrm{a}}$ \\
\hline
\end{tabular}

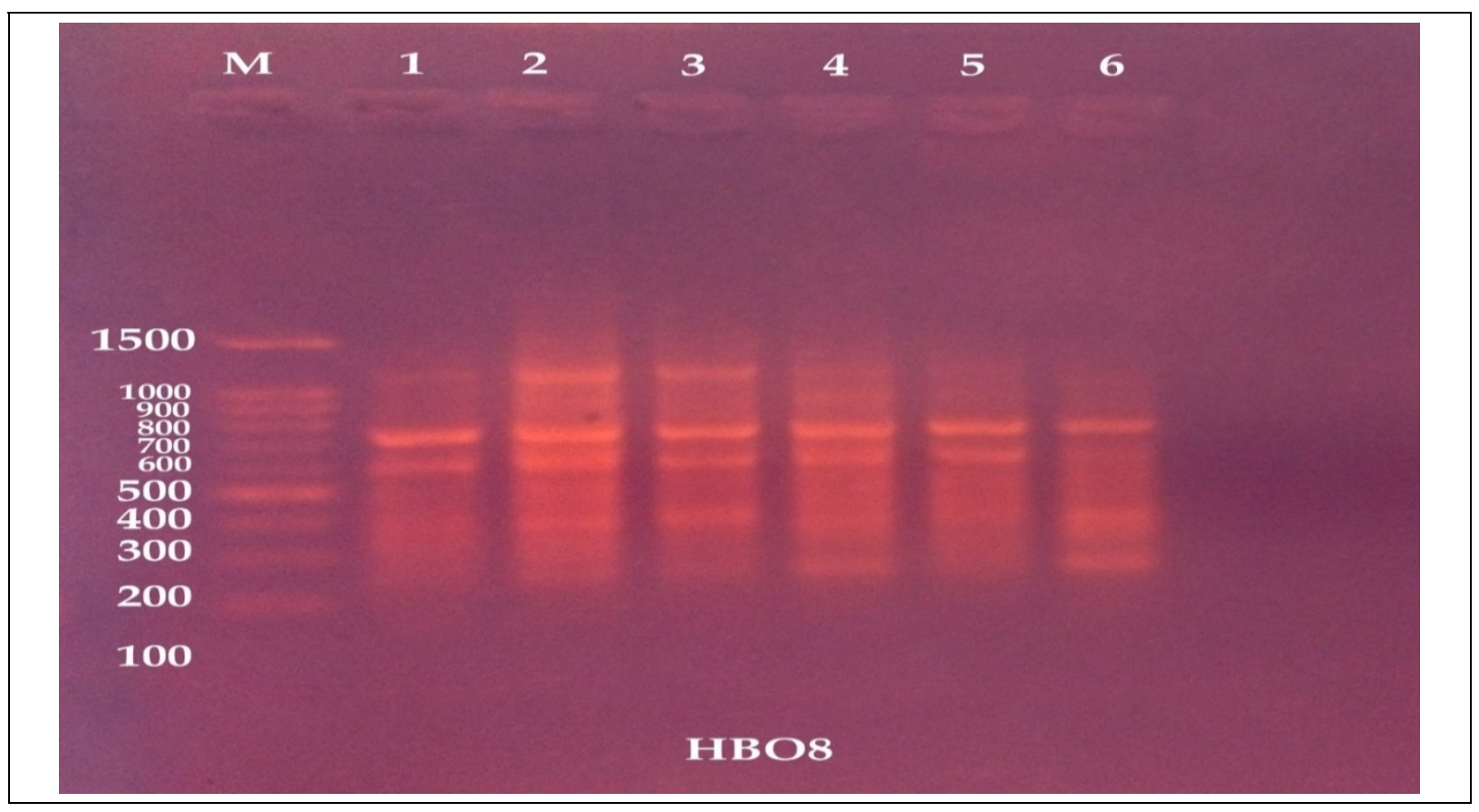

Fig. 2. Photograph of $1.5 \%$ agarose gel electrophoresis of the amplified PCR product of the isolated genomic DNA from leaves of the different six Canna varieties by using the random primer HB-O8 where: lane $\mathrm{M}=$ marker, 1- C1: Canna variegata, 2- C2: Canna indica red, 3- C3: Canna lily, 4- C4: Canna lily red brilliant, 5- C5: Canna flaccida, and 6- C6: Canna paniculata. 


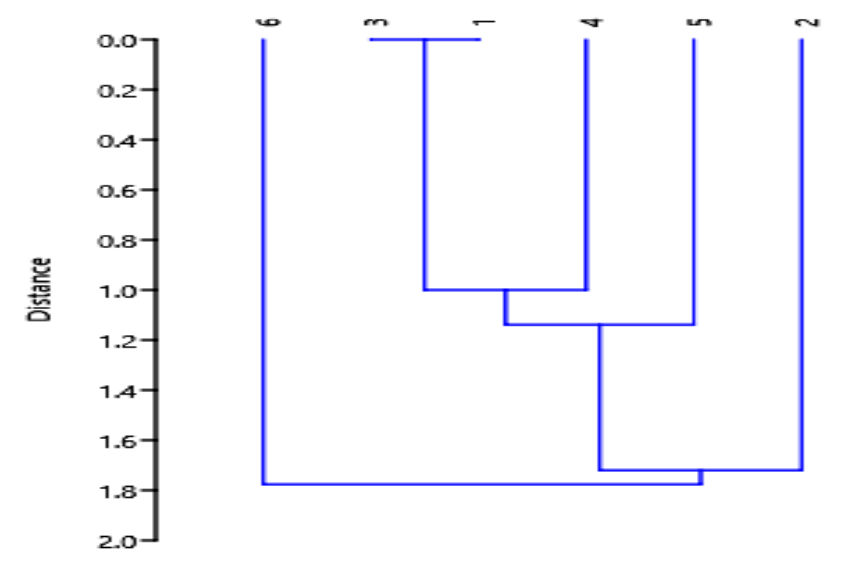

Fig. 3. Phylogenetic tree is a branching diagram used to show relationships between members of a group; a family tree. 1- C1: Canna variegata, 2- C2: Canna indica red, 3- C3: Canna lily, 4- C4: Canna lily red brilliant, 5- C5: Canna flaccida, and 6- C6: Canna paniculata.

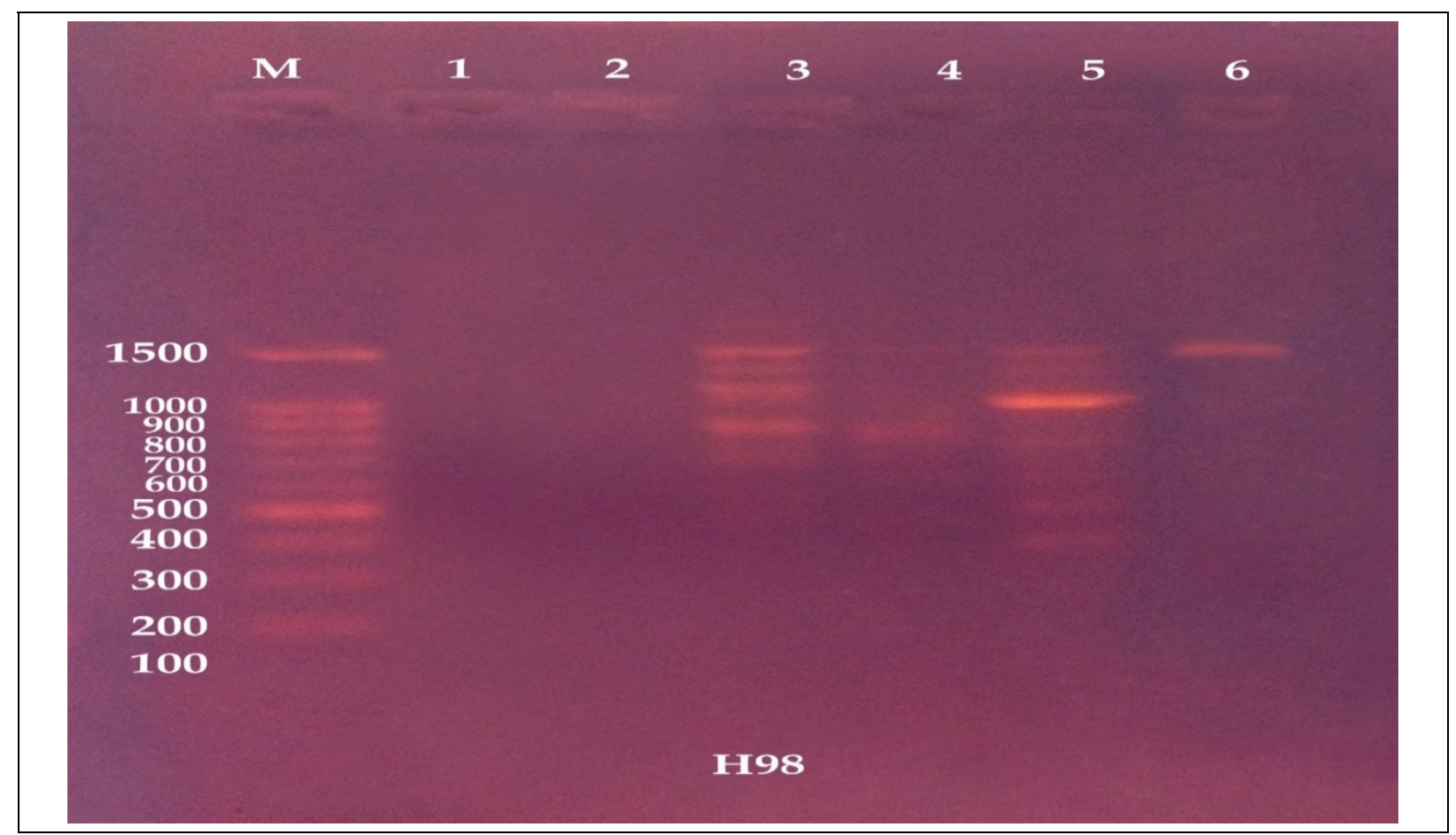

Fig. 4. Photograph of $1.5 \%$ agarose gel electrophoresis of the amplified PCR product of the isolated genomic DNA from leaves of the different six Canna varieties by using the random primer HA-98 where: lane $\mathrm{M}=$ marker, 1- C1: Canna variegata, 2- C2: Canna indica red, 3- C3: Canna lily, 4- C4: Canna lily red brilliant, 5- C5: Canna flaccida, and 6- C6: Canna paniculata. 


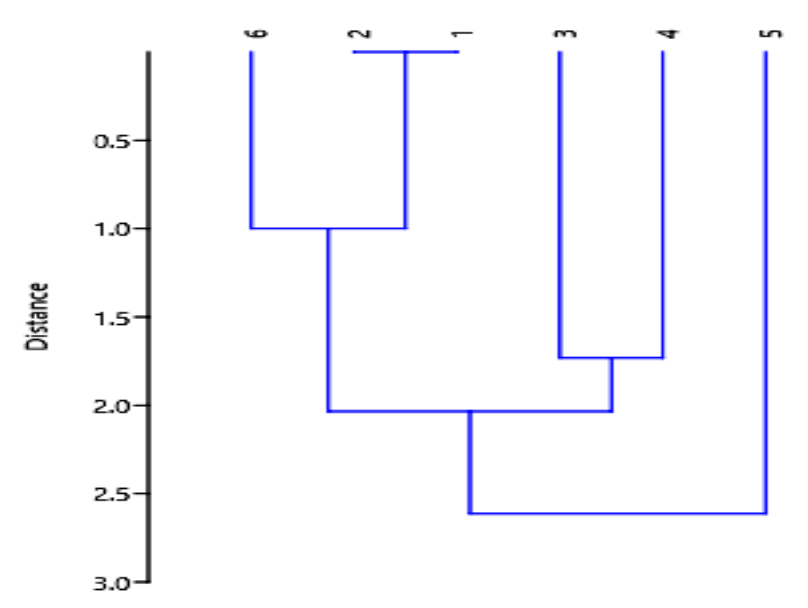

Fig. 5. Phylogenetic tree is a branching diagram used to show relationships between members of a group; a family tree. 1- C1: Canna variegata, 2- C2: Canna indica red, 3- C3: Canna lily, 4- C4: Canna lily red brilliant, 5- C5: Canna flaccida, and 6- C6: Canna paniculata.

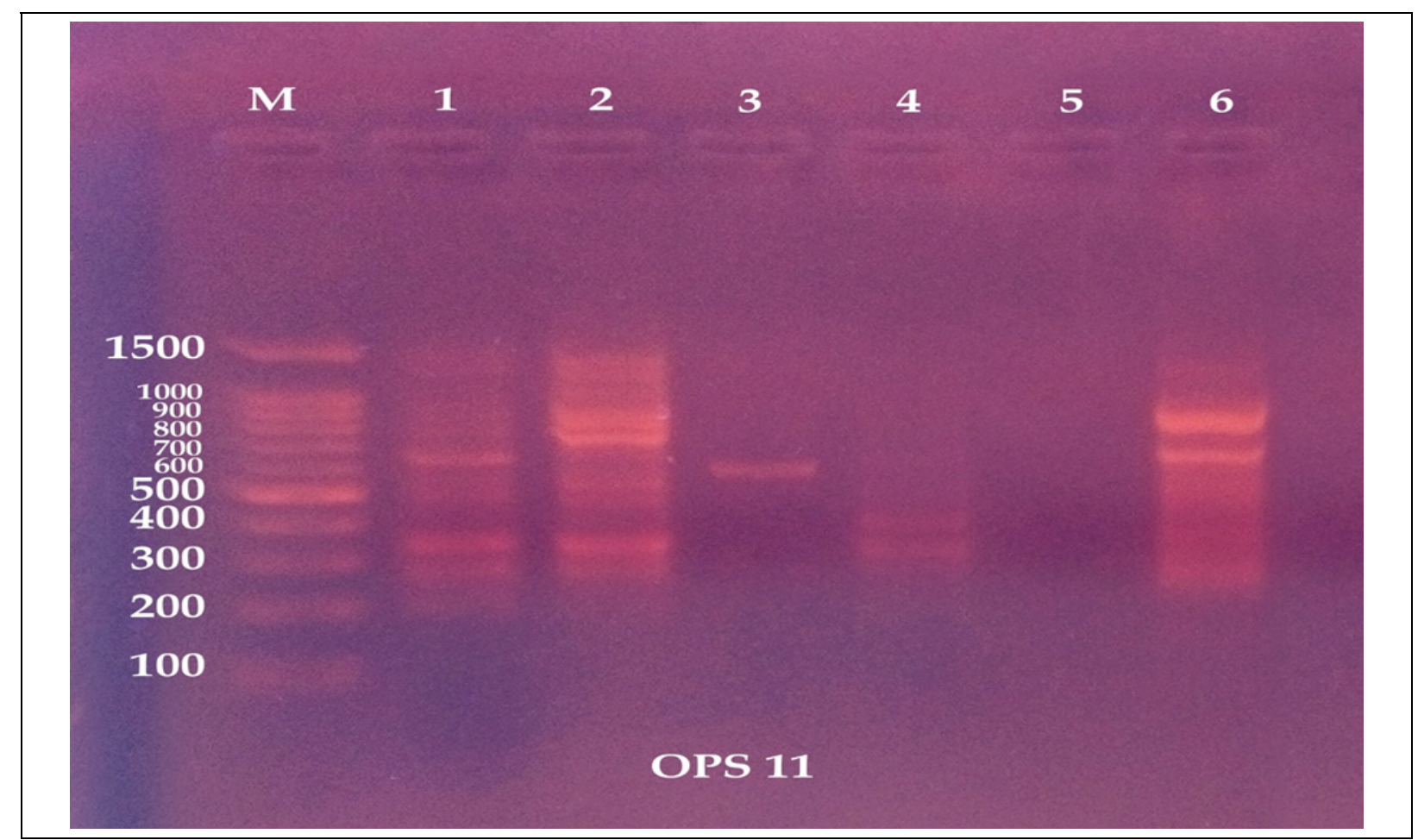

Fig. 6. Photograph of $1.5 \%$ agarose gel electrophoresis of the amplified PCR product of the isolated genomic DNA from leaves of the different six Canna varieties by using the random primer OPS-11 where: lane $M=$ marker, 1- C1: Canna variegata, 2- C2: Canna indica red, 3- C3: Canna lily, 4- C4: Canna lily red brilliant, 5- C5: Canna flaccida, and 6- C6: Canna paniculata. 


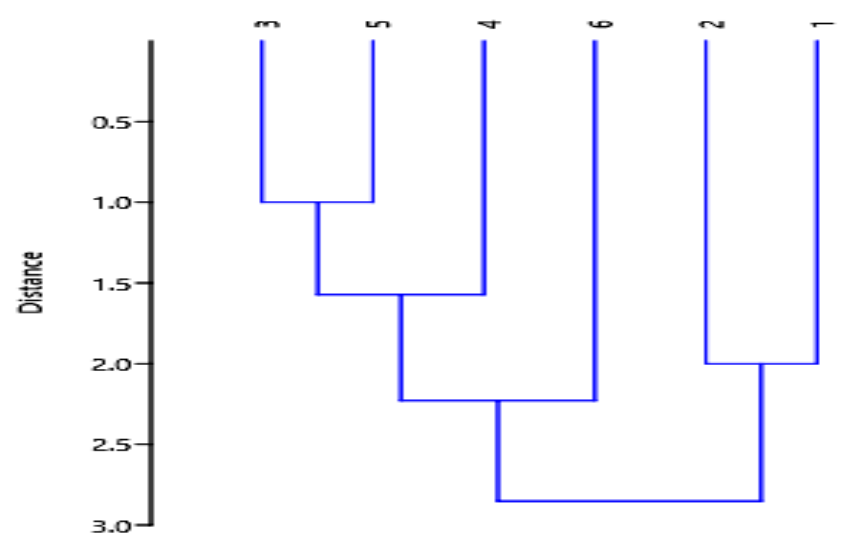

Fig. 7. Phylogenetic tree is a branching diagram used to show relationships between members of a group; a family tree. 1- C1: Canna variegata, 2- C2: Canna indica red, 3- C3: Canna lily, 4- C4: Canna lily red brilliant, 5- C5: Canna flaccida, and 6- C6: Canna paniculata.

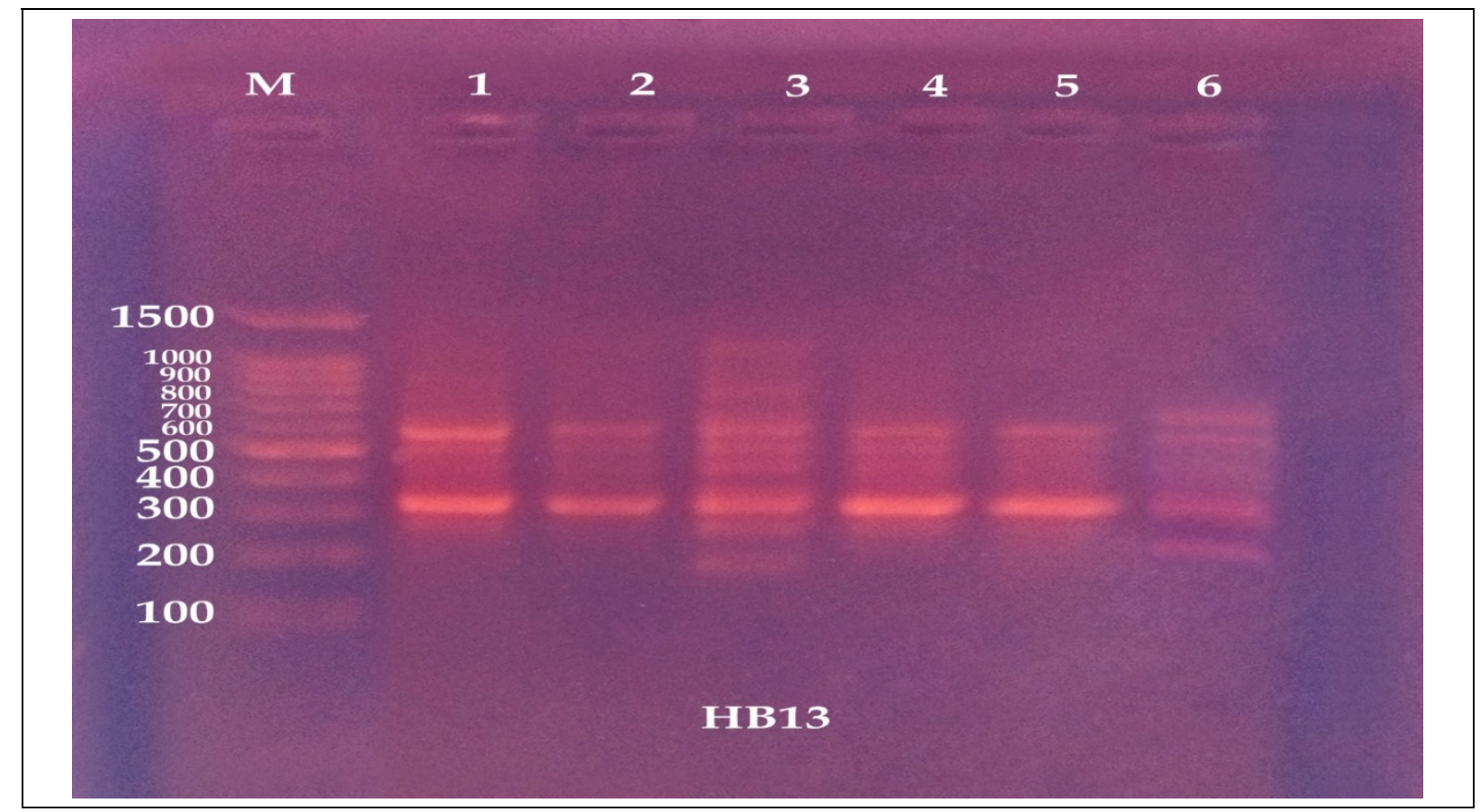

Fig. 8. Photograph of $1.5 \%$ agarose gel electrophoresis of the amplified PCR product of the isolated genomic DNA from leaves of the different six Canna varieties by using the random primer HB-13 where: lane $M=$ marker, 1- $C 1$ : Canna variegata, 2- C2: Canna indica red, 3- C3: Canna lily, 4- C4: Canna lily red brilliant, 5- C5: Canna flaccida, and 6- C6: Canna paniculata. 


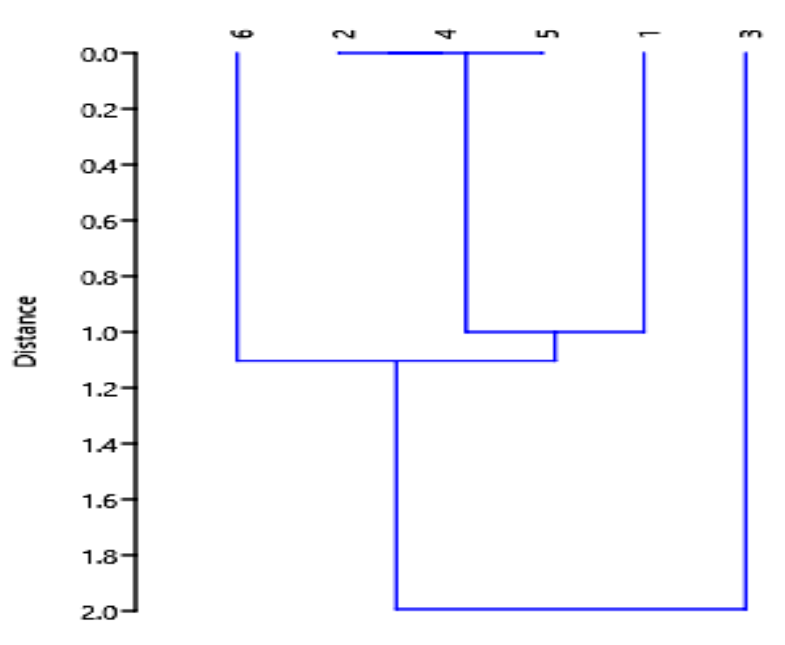

Fig. 9. Phylogenetic tree is a branching diagram used to show relationships between members of a group; a family tree. 1- C1: Canna variegata, 2- C2: Canna indica red, 3- C3: Canna lily, 4- C4: Canna lily red brilliant, 5- C5: Canna flaccida, and 6- C6: Canna paniculata.

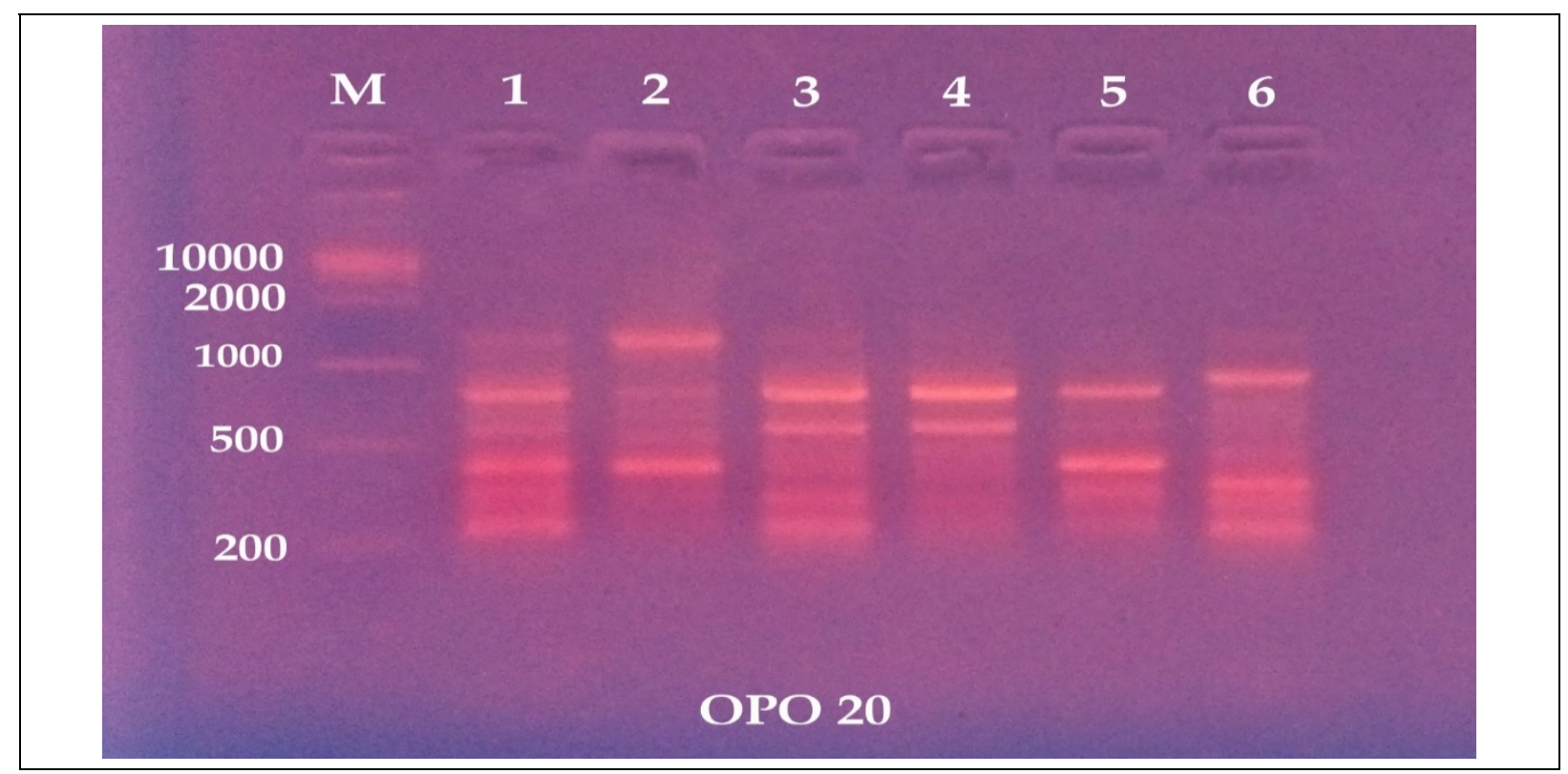

Fig. 10. Photograph of $1.5 \%$ agarose gel electrophoresis of the amplified PCR product of the isolated genomic DNA from leaves of the different six Canna varieties by using the random primer OPO-20 where: lane $\mathrm{M}=$ marker, 1- C1: Canna variegata, 2- C2: Canna indica red, 3- C3: Canna lily, 4- C4: Canna lily red brilliant, 5- C5: Canna flaccida, and 6- C6: Canna paniculata. 


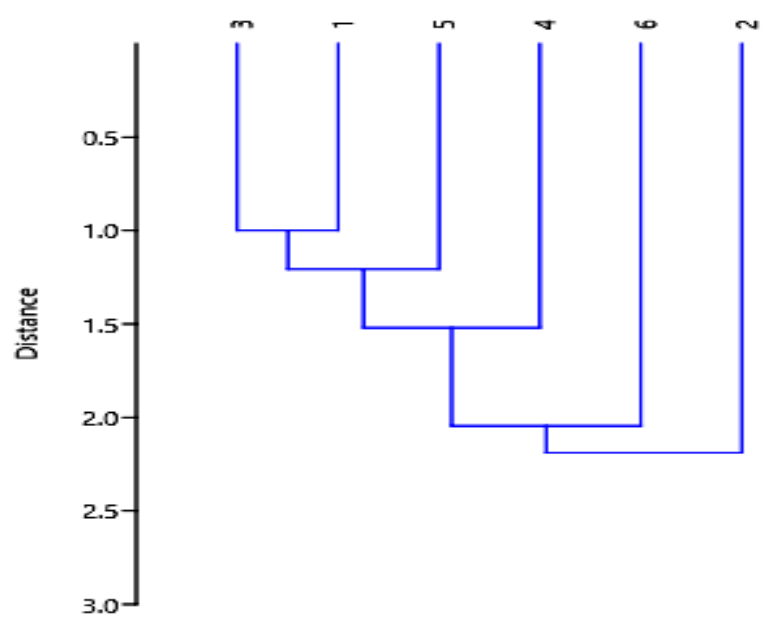

Fig. 11. Phylogenetic tree is a branching diagram used to show relationships between members of a group; a family tree. 1- C1: Canna variegata, 2- C2: Canna indica red, 3- C3: Canna lily, 4- C4: Canna lily red brilliant, 5- C5: Canna flaccida, and 6- C6: Canna paniculata.

Polygenic tree based on this primer (HBO8) as shown in Fig. (3) revealed that the different six Canna varieties were divided into two major clusters. Cluster (A) included varieties Canna variegata (C1), Canna indica red (C2), Canna lily (C3), Canna lily red brilliant (C4), and Canna flaccida (C5). On the other side (B) included Canna paniculata (C6). Furthermore, cluster (A) divided into two sub clusters as shown in this Fig. from the previous results in this primer we can concluded that Canna paniculata (C6) was too far from the other varieties in its polygenetic relationship. Also, we can deduce that varieties Canna variegata (C1) and Canna lily (C3) in a high degree of polygenetic relationship, while the rest of varieties were in a close relationship.

Fig. (4) showed the results of HA-98 primer which contains $47.67 \% \mathrm{G}+\mathrm{C}$ (Table, $1)$, it reacted with all six different Canna varieties used in the present study. The length of amplified DNA fragments of the PCR products generated by this primer ranged from 400-1500 bp as shown in this figure. The number of total amplified bands, where the lowest number is zero amplified bands in Canna variegata (C1) and Canna indica red (C2), while the highest number is nine in Canna flaccida (C5). The number of total amplified bands from the genomic of the tested six varieties was eleven which all were polymorphic giving $100 \%$ polymorphism.

In Fig. (5) phylogenic tree for this primer (HA-98) divided into two major clusters $\mathrm{A}$ and $\mathrm{B}$. The cluster $\mathrm{A}$ included Canna flaccida (C5) and the cluster B included two sub clusters (C and D), as (C) assembled Canna lily (C3) and Canna lily red brilliant (C4), while the other cluster (D) assembled varieties (C1) Canna variegata and (C2) Canna indica red and also included (C6) Canna paniculata.

On the other side, Fig. (6) showed the obtained results from OPS-11 primer which contains $60 \% \mathrm{G}+\mathrm{C}$ (Table, 1). The length of amplified DNA fragments of the PCR products generated by this primer ranged from 200-1500 bp. The total number of bands varied among all varieties except Canna flaccida (C5). In addition, the lowest number was one amplified band in Canna lily (C3), while the highest number nine in 
Canna indica red (C2). The total number of amplified bands the genomic of these six varieties and 13 polymorphic bands and no monomorphic bands were obtained. So, the polymorphism percentage was $100 \%$, and indicated that OPS-11 this primer had the highest percent of polymorphism.

Fig (7) showed the phylogenic tree of OPS-11 primer, it revealed that the six different varieties of Canna were divided into two major clusters $\mathrm{A}$ and $\mathrm{B}$. The cluster A included Canna variegata $(\mathrm{C} 1)$ and Canna indica red (C2), while the cluster (B) was divided into two sub-clusters $\mathrm{C}$ and $\mathrm{D}$. the sub-cluster (C) contained only the Canna paniculata (C6). However, the sub-cluster (D) contained varieties Canna lily (C3) Canna lily red brilliant (C4) and Canna flaccida (C5). It can be observed that (C3) Canna lily and Canna flaccida (C5) was in a close kinship with each other.

Results in Fig. (8), indicated that the random primer $\mathrm{HB}-13$ contains $72.73 \% \mathrm{G}+\mathrm{C}$ (Table, 1). The length of amplified DNA fragments of the PCR products generated by this primer ranged from $200-1500 \mathrm{bp}$. The number of total bands varied among varieties, where the lowest number was four amplified bands in Canna indica red (C2), Canna lily red brilliant (C4) and Canna flaccida (C5), while the highest number were eight amplified bands in the Canna lily (C3) variety. The total numbers of amplified bands from the genomic of the previous six varieties were nine, with 5 polymorphic bands and 4 monomorphic bands giving $55.5 \%$ polymorphism percentage, which indicated that this primer had the lowest percent of polymorphism.

Phylogenic tree represents the results of HB-13 primer (Fig., 9). It was observed that, the tree was divided into two major clusters. The cluster (A) contained (C3) Canna lily only. While the cluster (B) assumed the other varieties, which also divided into two subclusters. The sub-cluster (C) contained the following four varieties Canna variegata (C1), Canna indica red (C2), Canna lily red brilliant (C4) and Canna flaccida (C5).
These results revealed that the varieties $(\mathrm{C} 2)$ Canna indica red, Canna lily red (C4) and Canna flaccida (C5) were closed together.

The obtained results in Fig. (10), revealed that the random primer OPO-20 contains $60 \% \mathrm{G}+\mathrm{C}$ (Table, 1). The length of amplified DNA fragments of the PCR products generated by this primer ranged from $200 \mathrm{bp}$ to $1500 \mathrm{bp}$. The total number of bands varied among all examined varieties. On the other hand, lowest number were five amplified bands in these varieties Canna lily (C3), Canna lily red brilliant (C4), Canna flaccida (C5) and Canna paniculata (C6), while the highest number were six amplified bands in the Canna variegata $(\mathrm{C} 1)$ and Canna indica red (C2). The total numbers of amplified bands from the genomic of the previous six varieties were eight bands, where seven bands of them were polymorphic and only one monomorphic band.

Fig. (11) showed phylogenic tree based on OPO-20 primer, it presented that the tree divided into two major cluster. Cluster A included only Canna indica red (C2), while the other varieties were found in the two sub clusters of cluster B as shown in the upward. One of this sub clusters Canna variegata (C1) and Canna lily (C3) were joined together in a cluster which means that they are the nearest varieties in polymorphic relationship. The first one was Canna indica $\operatorname{red}(\mathrm{C} 2)$.

Table (4) summarized the total number of amplified bands, polymorphic bands and monomorphic bands as well as the percentage of polymorphism by using two RAPD and three ISSR primers. As shown in this Table, the obtained results revealed that all used primers produced a total of 49 amplified bands, which most of them were polymorphic bands with $83.6 \%$ percentage of polymorphism. These results also demonstrated that the presence of three different amplified unique bands in the genome Canna used as molecular markers to identify each one of these Canna varieties. On the other hand, a total of 49 major 
scorable bands ranging from 200 to $1500 \mathrm{bp}$ were generated from two RAPD and three ISSR primers showing $83.6 \%$ polymorphism.

As shown in Table (4), the numbers of the amplified bands varied for $8 \mathrm{HB}-\mathrm{O} 8$ and 13 OPS-11 bands primer, respectively, with total of 49 bands. On the other side, DNA lengths ranged from 200 to $1500 \mathrm{bp}$ for all varieties of Canna. It was recorded that the maximum number of the polymorphic bands (13) for primer OPS-11 with percentage polymorphism $100 \%$. On the contrary, the primer HB-13 exhibited the minimum number of the polymorphic bands (five) and also the minimum percent of polymorphism (55.5) similar results was reported by Piyachomkwan et al. (2002).

Similarity coefficient of the six Canna varieties ranged from 3.316 to 5.099 . It was found that, the lowest similarity degree (3.31) was between Canna flaccida (C5) and Canna lily red brilliant (C4) brilliant, while the highest 5.099 correlation was recorded between Canna lily (C3) and Canna indica red (C2) and also between Canna flaccida (C5) and Canna indica red (C2) (Table 5).
In the present study, UPGMA analyses were performed, and dendrograms were constructed. Based on RAPD, ISSR and combined data, two similar clusters with variable percentages of similarity were detected.

Rajaseger et al. (1997) analyzed the genetic diversity among 22 cultivars of Ixora through RAPD and found DNA markers useful in distinctly grouped under two clusters. All 22 cultivars distinctly grouped under two cultivars groups, viz., Ixora coccinea and I. javanica. The study indicated that besides the use of RAPD makers for identification of particular Ixora cultivars, the phylogenetic relationships generated by RAPD analysis might be useful for varietal improvement programs. It was observed in the present study that it was possible to segregate the used varieties of Canna through RAPD and ISSR markers using 5 random primers.

Five random decamer oligonucleotide primers were used for RAPD and ISSR analysis. The dendrogram constructed on the basis of the obtained data from both RAPD and ISSR analysis is represented in Fig. (12).

Table 4. Total number of amplified fragments and number of polymorphic fragments generated by PCR using selected RAPD and ISSR primers.

\begin{tabular}{ccccccc}
\hline Primer & $\begin{array}{c}\text { Total } \\
\text { number of } \\
\text { bands }\end{array}$ & $\begin{array}{c}\text { The length of } \\
\text { amplified DNA }\end{array}$ & $\begin{array}{c}\text { Monomorphic } \\
\text { bands }\end{array}$ & $\begin{array}{c}\text { Polymorphic } \\
\text { bands }\end{array}$ & $\begin{array}{c}\text { Unique } \\
\text { bands }\end{array}$ & polymorphism \% \\
\hline HB-O8 & 8 & $200-1500$ & 3 & 5 & 0 & 62.5 \\
HA-98 & 11 & $400-1500$ & 0 & 11 & 1 & 100 \\
OPS-11 & 13 & $200-1500$ & 0 & 13 & 0 & 100 \\
HB-13 & 9 & $200-1500$ & 4 & 5 & 2 & 55.5 \\
OPO-20 & 8 & $200-1500$ & 1 & 7 & 0 & 87.5 \\
Total & 49 & - & 8 & 41 & 3 & 83.6 \\
\hline
\end{tabular}

Table 5. Similarity based upon the genetic distance among the different six Canna varieties by Euclidean for 5 random Primers of RAPD and ISSR.

\begin{tabular}{lllllll}
\hline \multicolumn{1}{c}{ Canna varieties } & C1 & C2 & C3 & C4 & C5 & C6 \\
\hline C1: Canna variegata & 0 & & & & & \\
C2: Canna indica red & 3.464 & 0 & & & & \\
C3: Canna lily & 4.242 & 5.099 & 0 & & & \\
C4: Canna lily red brilliant & 4.358 & 4.582 & 3.605 & 0 & & \\
C5: Canna flaccida & 4.472 & 5.099 & 3.464 & 3.316 & 0 & \\
C6: Canna paniculata & 3.605 & 4.358 & 4.582 & 4.472 & 4.358 & 0 \\
\hline
\end{tabular}




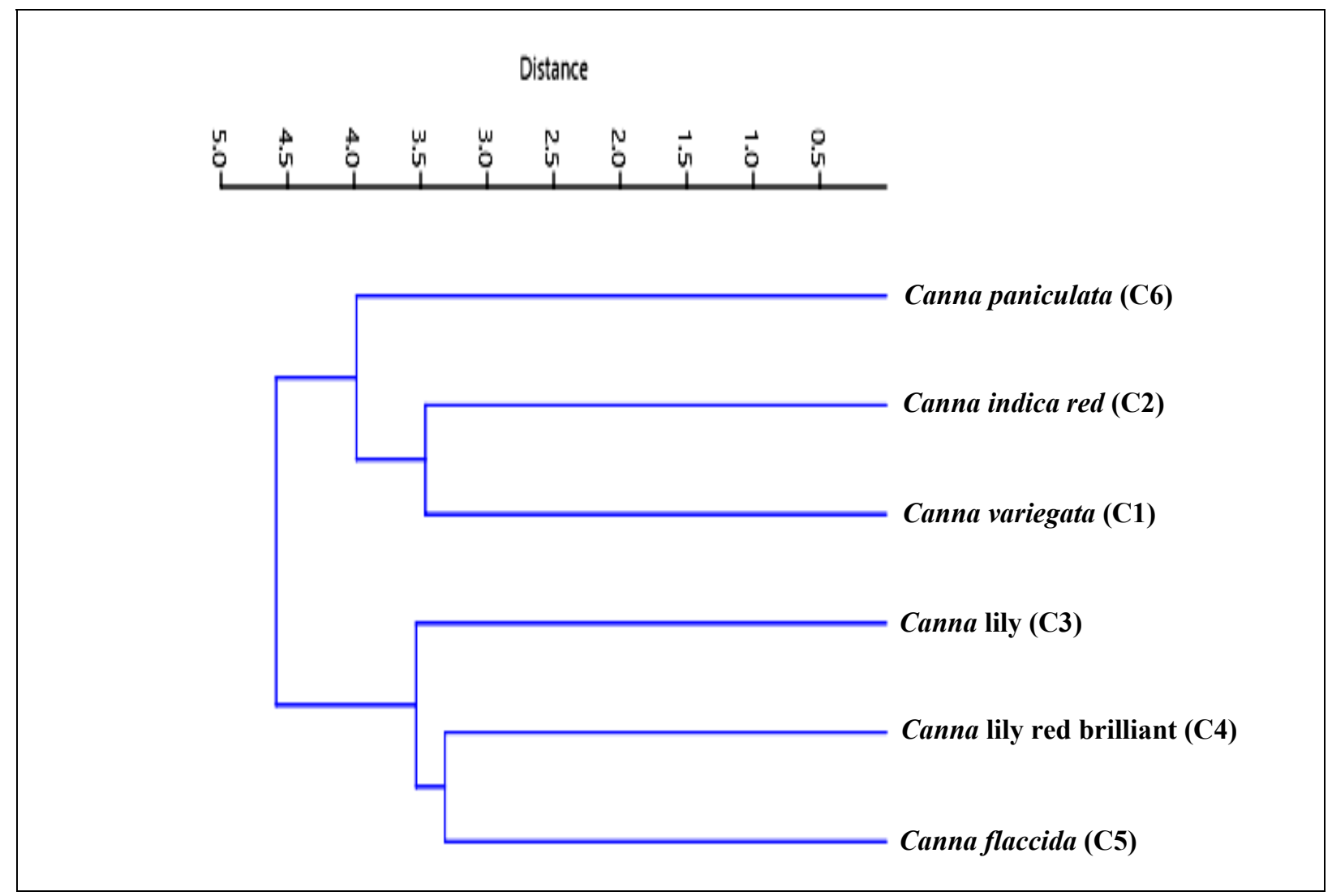

Fig. 12. Phylogenetic tree is a branching diagram used to show relationships between members of a group; a family tree. 1- C1: Canna variegata, 2- C2: Canna indica red, 3- C3: Canna lily, 4- C4: Canna lily red brilliant, 5- C5: Canna flaccida, and 6- C6: Canna paniculata.

Furthermore, dendrogram showed two similar clusters with variable percentage of similarity. It can be concluded that, cluster (A) was assumed Canna variegata $(\mathrm{C} 1)$ and Canna indica red $(\mathrm{C} 2)$ in sub cluster $(\mathrm{C})$, in addition, this cluster had Canna paniculata (C6) in subcluster (D). It was observed that all these cultivars had same flower colour which were orange. However, they were completely different in leaves colours. So, it can be detected that varieties of Canna with orange flowers can be grouped together in large cluster. It was hypothesized that the group of these cultivars were clustered together to form a somaclone complex, which might have originated from somatic mutation of cultivars (Ude et al., 2003). These findings were in accordance with Patra et al. (2008), where morphologic characters were focused in discussing the molecular variability of different cultivars of Canna. In this study, morphological character was considered for analyzing the genetic variability.

On the other side, cluster (B) was assumed Canna flaccida (C5) and Canna lily red brilliant (C4) in sub cluster (E) with green leaves, yellow flower and red flower respectively. It also concluded Canna lily with green leaves and white flower which was represented in subcluster (F). It can be observed that, in this cluster (B), all varieties shared with green leaves with different flower colours.

Most of these obtained results of phylogenic tree were corresponded with Piyachomkwan et al. (2002), who mentioned that high level of genetic similarity was found between indogenous of Canna edulis. 
It can be concluded that the varieties cannot be segregated from somaclone complex which based on plant height, flower colour and shape, but also some intraspecific genome relationship might be considered (Mishra et al., 2012).

The inter-relationship obtained from RAPD and ISSR analysis in Canna were in agreement with the findings of Loh et al. (1999) who made AFLP analysis of two species and 7 cultivars of Caladium and inferred that closely related species can clearly be differentiated and the genetic difference between cultivars can be also established. Furthermore, the findings in the present study were in agreement with the results of Loh et al. (1999) who indicated that, at intra-shied that, at intra-specific level, two preliminary clusters could be identified in Caladium bicolor, one group contains the "fancy leaf" cultivars and the other group with "Strap leaf" cultivars. The apparent explanation offered was that in Caladium, difference in leaf shape might be due to allelic difference indicative of the fact that the dichotomy between fancy leaf and at Strap leaf may not be a very strong taxonomic character. Same inference may be drawn as to the flower colour in Canna and the reason for varieties having same flower colour came together in the same cluster, and also the varieties having same leaves colour came together in the other cluster.

In nature, Canna seems to have been evolved essentially by gene mutation and repattering of chromosomes. Man's interference led to recombination emanating from inter-specific hybridization, somatic mutation and triploid has speeded up the process of evolution (Khoshoo, 1979; Khoshoo and Mukherjee, 1970). The natural variability was also widening by spontaneously occurring mutations although the rate of such occurrence is very low (Patra et al., 2008).

This investigation demonstrated that both of RAPD and ISSR offers a suitable means for detecting genetic diversity in Canna.

From the previous figure, it can be represented that Canna indica red (C2) and Canna lily (C3) were in a high polymorphic relationship (Fig., 13). Also, Canna paniculata (C6) had the lowest relationship compared with the other used varieties.

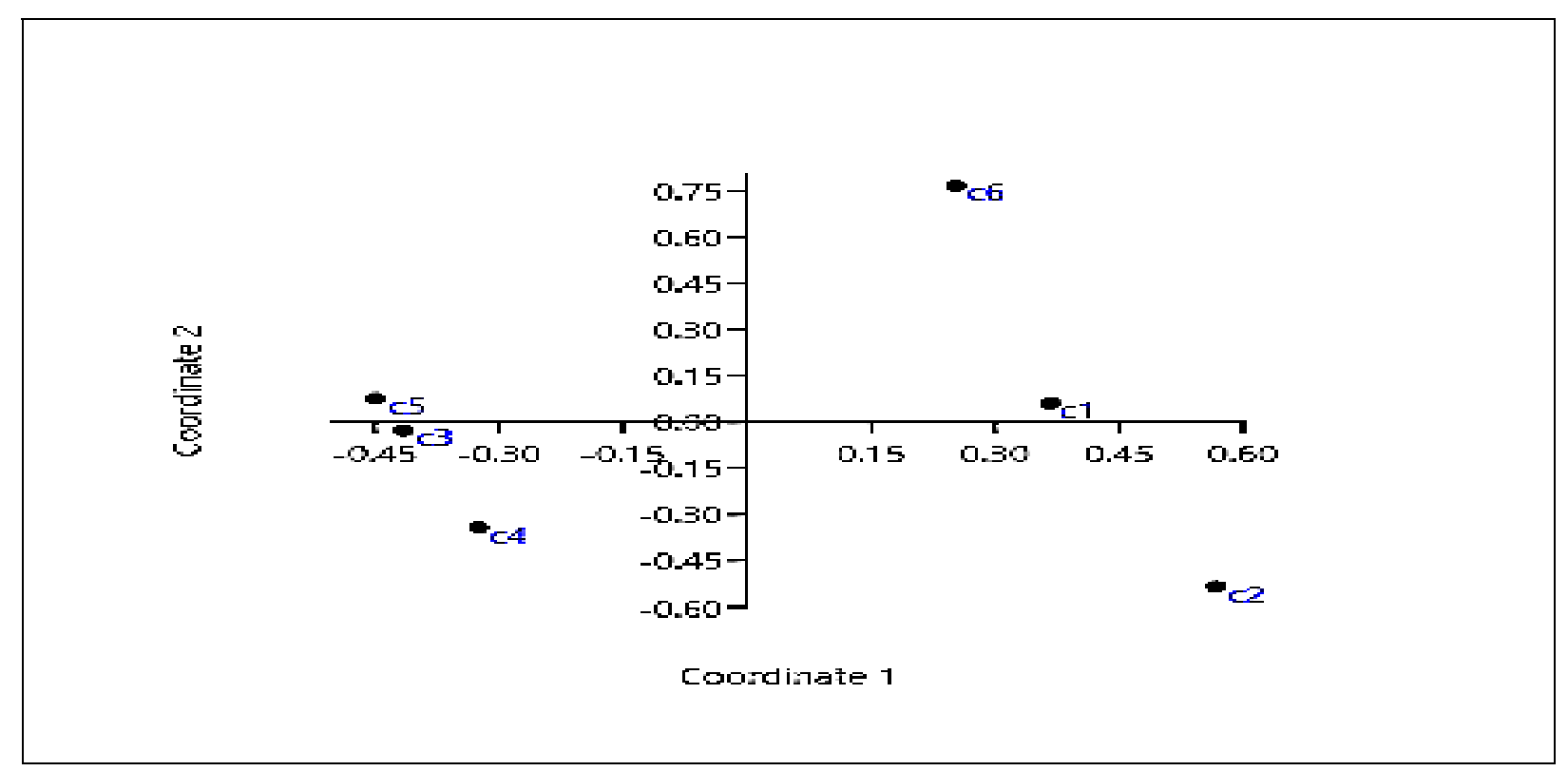

Fig. 13. Principal coordinate analysis (2-dimensional plot) of six varieties of Canna based on combined RAPD and ISSR analysis data. 


\section{CONCLUSION}

It can be deduced that a total of 49 major scorable bands ranging from 200 to $1500 \mathrm{bp}$ were generated from two RAPD and three ISSR primers showing $83.6 \%$ polymorphism. In addition, it was observed that Canna paniculata (C6) always in a far correlation with the other varieties used in this study. On the other hand, Canna lily (C3) and Canna indica red brilliant (C2) had the highest correlation (5.09), also Canna flaccida (C5) and Canna indica (C2) gave the same results. While, the lowest similarity (3.316) was observed between Canna lily red brilliant (C2) and Canna flaccida (C5). The dendrogram showed that the used primers divided the used Canna varieties into two groups according to the leaves colours and the flowers colours.

\section{REFERENCES}

Doyle, J.J. and Doyle, J.L. (1987). A rapid DNA isolation procedure for small quantities of fresh leaf tissue. Phytochemical Bulletin, 19:11-15.

Gupta, A.; Maurya, R.; Roy, R.; Solwant, R.K. and Yadav, H.K. (2013). AFLP based genetic relationship and population structure analysis of canna-An ornamental plant. Scientia Horticulture, 154:1-7.

Jaccard, P. (1908). Nouvelle researches sur la distribution florale. Bulletin de la Socit Vaudoise des Sciences Naturelles, 44:223-270.

Khoshoo TN. (1979). Cytogenetics in relation to plant evolution and improvement. In: Khoshoo, T.N. and Nair, P.K.K. (eds), Progress in Plant Research, Vol. 2, Silver Jubilee Publication, National Botanical Research Institute, pp. 1-74.

Khoshoo, T.N. and Mukherjee, I. (1970). Genetic-evolutionary studies on cultivated Canna, III. Variation in meiotic system. La Cellule, 68:109-134.
Legendre, P. and Anderson, M.J. (1999). Distance based redundancy analysis: testing multispecies responses in multifactorial ecological experiments. Ecological Monographs, 69:1-24.

Loh, J.P.; Kiew, R.; Kee, A.; Gan, L.H. and Gan, Y.Y. (1999). Amplified fragment length polymorphism (AFLP) provides molecular markers for the identification of Caladium bicolour cultivars. Annals of Botany, 84:155-161.

Mass-Van de, K.H. and Maas, P.J.M. (2008). The Cannaceae of the world. BlueaBiodiversty, Evolution and Biogeography of plants, 53: 247-318.

Mishra, T.; Goyal, A.K. and Sen, A. (2018). Molecular profiling of 20 different accessions of canna using RAPD and ISSR primers. Molecular Cytogenetics Laboratory, Department of Botany, University of North Bengal, Siliguri734013, West Bengal. An international journal of environment and biodiversity 9: 180-187.

Nei, M. (1972). Genetic distance between populations. American Naturalist, 106: 283-292.

Patra, B.; Acharya, L.; Mukherjee, A.K.; Panda, M.K. and Panda, P.C. (2008). Molecular characterization of ten cultivars of canna lilies (Canna Linn.) using PCR based molecular markers (RAPDs and ISSRs). International Journal of Integrative Biology, 2:129137.

Piyachomkwan, K.; Chotineeranat, S.; Kijkhunasatian, C.; Tonwitowat, R.; Prammanee, S.; Oates, C.G. and Sriroth, K. (2002). Edible canna (Canna edulis) as a complementary starch source to cassava for the starch industry. Industrial Crops and Products, 16:11-21.

Prince, L.M. (2010). Phylogenetic relationship and species delimitation in Canna (Cannaceae). In: Seberg, O., Petersen, G.; Barford, A.S. and Davis, J.I. (eds.), Diversity, Phylogeny, and 
Evolution in The Monocotyledons, Aarhus University Press, Denemark, pp. 307-331.

Rajasegar, G.; Tan, H.T.W.; Turner, I.M. and Kumar, P.P. (1999). Random amplified polymorphic DNA variation among and within selected Ixora (Rubiaceae) populations and mutants. Annals of Botany, 84: 253-257.

Rajaseger, G.; Tan, H.T.W.; Turner, I.M. and Kumar, P.P. (1997). Analysis of genetic diversity among Ixora cultivars (Rubiaceae) using random amplified polymorphic DNA. Annals of Botany, 80: 355-361.

Rohlf, F.J. (1998) NTSYS-Pc. Numerical taxonomy and multivariate analysis system version 2.02e. Exeter Software. New York, USA.

Ude, G.; Pillay, M.; Ogundiwin, E. and Tenkouano, A. (2003). Genetic diversity in an African plantain core collection using AFLP and RAPD markers. Theoretical and Applied Genetics, 107: 248-25.

Yeh, F.C.; Yang, R.C.; Boyle, T.B.J.; Ye, Z.H. and Mao, J.X. (1997). PopGene, the user-friendly shareware for population genetic analysis, molecular biology and biotechnology center. University of Alberta, Canada.

\section{القرابة الوراثية بين أصناف وأنواع مختلفة من نبات الكنا باستخدام الواسمات الجزيئية}

$$
\text { قسم بحوث نباتات الزينة وتتسيق الحدائق (الإسكندرية)، معهد بحوث الزين التونيّين، مركز البحوث الزر اعية، الجيزة، مصر }
$$

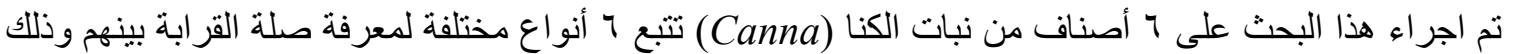

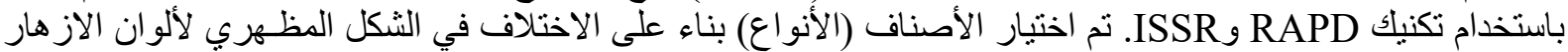

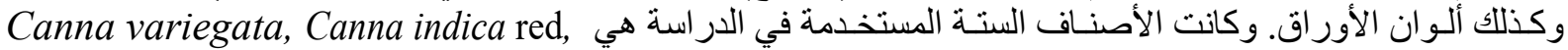
جأس Canna flaccida, Canna lily, Canna lily red brilliant جزيئية (اثنان من نظام RAPD وثلاثة من نظام ISSR) علي الاصناف الستة. وكانت النتائج كما يلي: وجد مجموع بالئ

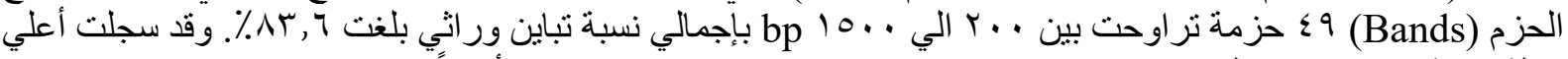

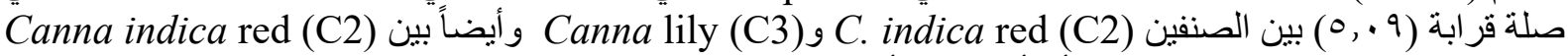

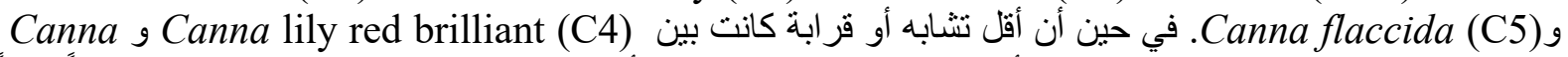
flaccida (C5) جداً عن باقي الأصناف المختبرة. وقد لوحظ أن البادئات الجزيئية المستخدمة قسمت الألية الأصناف إلى مجمو عتين رئيسيتين

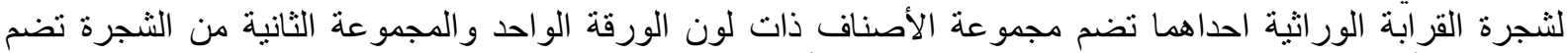

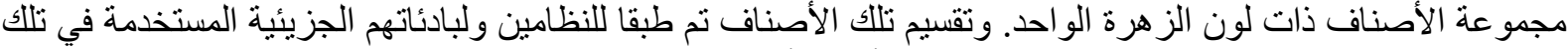
الدر اسة، و التي ربما تعطى نتائج مختلفة لو التنخدمت النظمة أنظة أخرى وبادئات متباينة. 